\title{
Presumptive Y/D Translocation in Mixed Gonadal Dysgenesis*
}

\author{
DANIEL D. FEDERMAN, FRANK M. DAVIDOFF, and EILEEN OUELLETTE
}

From the Department of Medicine (Endocrine Unit), Massachusetts General Hospital and Harvard Medical School, $\frac{\stackrel{\Omega}{3}}{3}$ and the Walter E. Fernald State School, Boston, Massachusetts, U.S.A.

One of the important findings of human cytogenetics has been the role of the $\mathrm{Y}$ chromosome in testicular differentiation of the bipotential embryonic gonad, but a puzzle has been posed by reports of individuals with a testis but with no apparent $\mathrm{Y}$ chromosome. This paper describes a patient with mixed gonadal dysgenesis (testis and streak), interpreted as having a $\mathrm{Y} / \mathrm{D}$ translocation in some cells, the rest being XO.

\section{Case Report}

R. L. (M. G. H. No. 136-36-6I) was born at term in a breech delivery to a 32 -year-old mother (gravida I para 0 ), and a 32-year-old father. Ambiguous genitalia were noted at birth with an enlarged nonpatent phallus, a bifid scrotum, and no palpable testes, and the patient was reared as a male until the age of 4 . At that time laparotomy disclosed what was thought to be a normal-appearing ovary and a para-ovarian cyst on the left side and a series of rudimentary cystic structures on the right. No uterus was clearly distinguished, but running transversely and closely applied to the bladder was a white, string-like, apparently solid structure connecting the two rudimentary broad ligaments and their abnormal adnexa. The left para-ovarian cyst and the cystic structures on the right side were removed, and bilateral herniorrhaphies were performed. Microscopical examination of the cystic structures suggested a persistent mesonephros. There was no tissue suggestive of seminiferous tubules or Leydig cells. At the age of 9 the hypertrophied clitoris was amputated. It showed no penile urethra.

At the age of $9 \frac{1}{2}$ the patient was admitted to the Walter E. Fernald State School with an IQ of $5 \mathrm{I}$. She first showed evidence of virilism at 13, with a boyish body contour, facial and extensive leg hair, a male escutcheon, and deepening of the voice. Neither breast development nor periods appeared. At 18 chronic pyelonephritis was found, and at 23 , an abdominal mass was found and she

\footnotetext{
Received October 3, 1966.

* Supported in part by USPHS Grant AM 4501 and TI AM 5205 and Children's Bureau Training Grant No. 238.
}

was referred to the Massachusetts General Hospital. $\vec{\omega}$ The height was $146 \mathrm{~cm}$., weight $38 \mathrm{~kg}$., head circum- $\omega$ ference $54 \mathrm{~cm}$., arm span $149 \mathrm{~cm}$., pubis to crown 71 응 $\mathrm{cm}$., and pubis to sole $75 \mathrm{~cm}$. There was generalized hirsutism and moderate acne. The face was asymmetrical, $z$ the left side being higher than the right. Epicanthal remnants were present bilaterally, the hairline was low, $\frac{\rho}{\partial}$ and she had chronic otitis media. There was no webbing. $\vec{\bullet}$ The thyroid was not enlarged. Nipples were widely $\mathscr{O}$ spaced, and no breast tissue was palpable. The chest. was asymmetrical with a marked lumbar kyphoscoliosis. I The heart was normal. A mass $10 \times 10 \mathrm{~cm}$. was intermittently palpable below the umbilicus, with a $2 \times 4$ $\mathrm{cm}$. lobular extension into the right lower quadrant. Empty labioscrotal folds were fused except for a $0.5 \mathrm{~cm}$. के midline aperture through which urine passed. On rectal examination, no cervix or uterus was clearly felt, $\overrightarrow{0}$ though a midline mass was intermittently palpable. 3 The carrying angle was increased; the large hands showed no clinodactyly or simian creases. Dermatoglyphic analysis showed a high ridge count (over 207), ulnar hypothenar loops, and high atd angles. She was a shy co-operative person who spoke rarely and with a low $\dot{\sigma}$ hoarse voice. She understood and followed commands, and was capable of total self care. There were no focal 8 neurological signs.

Urinalysis was negative save for $15 \mathrm{WBC} /$ high power $\mathrm{O}$ field. Intravenous pyelogram showed a double collecting system bilaterally, with marked blunting and calyectasis $\frac{7}{2}$ of the left kidney, and hydronephrosis and hydroureter on the left side. Protein-bound iodine was $5.7 \mu \mathrm{g}$./ O I00 $\mathrm{ml}$. Radioactive iodine uptake was $19 \%$; following $\mathrm{N}$ 5 units of thyroid stimulating hormone (TSH), the uptake 0 rose to $57 \%$. Antibodies to thyroglobulin (tanned red $\mathrm{\omega}$ cells) were present at a titre of $I: 80$. Immunofluorescence of thyroid antibodies revealed a stronge positive reaction to colloidal and cytoplasmic antigens. $\frac{\mathbb{D}}{\mathrm{C}}$

Although the abdominal mass was not constantly $\stackrel{?}{+}$ palpable, laparotomy was carried out because of the 0 risk of neoplasm in dysgenetic gonads. The most $\bar{O}$ striking abnormality was a distended uterus, measuring $\vec{\otimes}$ $8 \times 10 \mathrm{~cm}$., containing clear yellow fluid. There were $\underset{\mathbb{D}}{\mathbb{D}}$ bilateral rudimentary Fallopian tubes. On the right, $\cong$ parallel to and beneath the tube, was a thin fibrous 
streak. In a similar position at the outer third of the left tube was a gonad measuring $2 \times 1 \cdot 0 \times I \cdot 5 \mathrm{~cm}$. Histologically, the uterus showed a relatively welldeveloped myometrium and an endometrium, with transitional cell metaplasia and chronic inflammation. The right streak gonad showed dysgenetic ovarian stroma and nests of hilar cells but no follicles. The left gonad was a testis with an epididymis but no vas. There was hyalinization of the basement membrane of the tubules; the latter were lined by Sertoli cells and showed no spermatogenesis. Leydig cells, some of which contained crystalloids of Reinke, were abundant.

In retrospect, the abdominal mass occasionally felt before operation was apparently the uterus intermittently filled with urine. We assume that after leaving the bladder, urine was secreted so slowly through the minute opening in the labio-scrotal folds that pressure, built up in the urogenital sinus, was sufficient to force urine through the cervical os. This would at times produce a palpable mass; at other times this would be spontaneously decompressed by micturition.

Family Data. The parents have since had two normal daughters who have matured normally sexually. There is no family history of mental retardation or menstrual abnormality.

Methods. Urinary I7-hydroxycorticoids and I7ketosteroids were measured by the methods of Silber and Porter (1954) and of Epstein (1962), respectively. Plasma testosterone was kindly determined by Drs. Kliman and Briefer, by the double isotope dilution method (1964). Cytogenetic studies were carried out according to modifications of the methods of Klinger and Schwarzacher (1962) and Moorhead, Nowell, Mellman, Battips, and Hungerford (1960). Blood cells were harvested at three days; solid tissues were examined after the first subculture.

\section{Results}

Endocrinological Findings. The endocrinological investigations are summarized in Table $\mathrm{I}$.
17-OH corticoid excretion was normal in the control period and responded promptly to dexamethasone suppression before and after operation. Before gonadectomy, the basal urinary 17-ketosteroids were within normal limits; dexamethasone produced less suppression than is usual, and chorionic gonadotropin (APL) (5000 $\mu$ daily, for four days) elicited a slight increase in ketosteroid output. After removal of the testis, the resting 17-ketosteroid output was somewhat lower, dexamethasone suppression was normal, and chorionic gonadotropin had no effect.

Before operation, the plasma testosterone level was $0.52 \mu \mathrm{g} / 100 \mathrm{ml}$. (normal for male $>0.3 \mu \mathrm{g} /$ $100 \mathrm{ml}$., for female $<0.1 \mu \mathrm{g} . / 100 \mathrm{ml}$.) and rose to $\mathrm{I} \cdot 04 \mu \mathrm{g} . / 100 \mathrm{ml}$. after four days of APL. After orchiectomy, the level was $0.09 \mu \mathrm{g} . / 100 \mathrm{ml}$. The 24-hour urinary gonadotropin values were 26 and 28 rat units before operation and 43 rat units afterwards. Both values are high for a 23 -year-old man or woman.

Cytological Findings. Dr. Priscilla Taft kindly examined the buccal smear and cultured tissues and found they were all chromatin negative. The cytogenetic findings are summarized in Table II. Six tissues were examined, and all had a consistent modal number of 45 chromosomes. The blood, skin, and uterus showed a uniform karyotype consistent with an XO chromosome constitution. The lymph node, streak, and testis, however, showed karyotypic mosaicism with two cell lines (Fig.). One line of cells was identical with the 45/XO pattern of the other tissues. The other cells formally lacked a member of the D group and had 16 chromosomes in the 6-12 $+\mathrm{X}$ group. We have interpreted these as cells with a Y/D translocation with 15 chromosomes in the 6-12 + $\mathrm{X}$ group.

TABLE I

ENDOCRINOLOGICAL INVESTIGATIONS

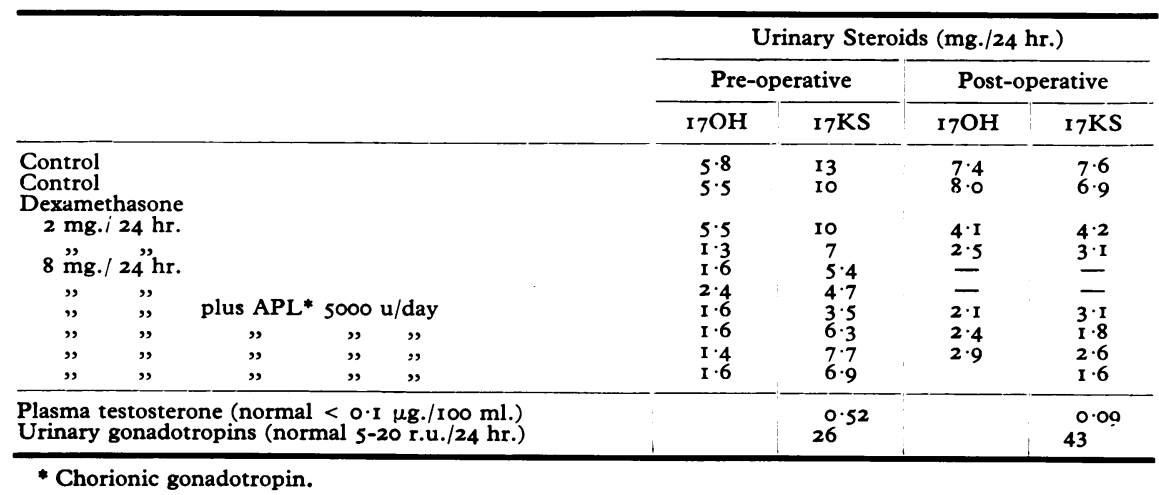


The only family member available for study was the father. Cytogenetic study of his cultured leucocytes showed a normal male karyotype.

\section{Discussion}

The clinical findings in this patient conform best to the syndrome of mixed or atypical gonadal dysgenesis, a term suggested by Sohval (1964). Greenblatt (1958) had earlier recognized that such patients provided a nosological connexion between gonadal dysgenesis (Turner's syndrome) and male pseudohermaphroditism. The usual picture in 
TABLE II

CYTOLOGICAL DATA

\begin{tabular}{|c|c|c|c|c|c|c|}
\hline & & 45 & & 45 & & 46 \\
\hline & & & XO & & $\underset{\mathrm{D}}{\mathrm{XY}} \sim$ & \\
\hline $\begin{array}{l}\text { Skin } \\
\text { Blood } \\
\text { Lymph node } \\
\text { Uterus } \\
\text { Streak } \\
\text { Testis }\end{array}$ & $\begin{array}{l}\left\{\begin{array}{l}\text { Counted } \\
\text { Karyotyped }\end{array}\right. \\
\text { Counted } \\
\text { Karyotyped } \\
\text { Counted } \\
\text { Karyotyped } \\
\text { Counted } \\
\text { Karyotyped } \\
\text { Counted } \\
\text { Karyotyped } \\
\text { Counted } \\
\text { Karyotyped }\end{array}$ & 2 & $\begin{array}{l}6 \\
6 \\
5\end{array}$ & $\begin{array}{l}25 \\
49 \\
20 \\
20 \\
20 \\
24\end{array}$ & $\begin{array}{l}\text { I } \\
0 \\
5 \\
9\end{array}$ & $\begin{array}{l}I^{*} \\
I^{\prime}\end{array}$ \\
\hline
\end{tabular}

* Extra in C Group.

mixed gonadal dysgenesis is a phenotypic female with a uterus and Fallopian tubes, a testis (or gonadal tumour), and a streak gonad internally, and slight external virilization.

The endocrinological data reported here show that the endocrine function of the single testis in this syndrome can be entirely normal. The plasma testosterone was in the normal male range and rose normally in response to APL. Before the operation, the urinary 17 -ketosteroids were incompletely suppressed by dexamethasone and were increased by APL, whereas after gonadectomy the basal levels were lower, dexamethasone produced greater suppression, and APL had no effect.

Cytogenetically the chromosome mosaicism indicates that an error occurred in mitosis; we suggest that the interchange took place in a normal $X Y$ zygote, and since no true $46 / \mathrm{XY}$ cells were found, it could have happened at the first division of the zygote. The sex phenotype of the patient favours our interpretation of an interchange involving the $\mathrm{Y}$ chromosome. Ferguson-Smith and Handmaker (1963) have shown that the Y chromosome, though not satellited, undergoes a significant number of associations with other chromosomes in metaphase. Thus, also on this ground, the background for a translocation between the $\mathrm{Y}$ and other chromosomes exists.

The formal interpretation of a missing member of group D and an extra chromosome in group C is unlikely on several counts. Since the patient is chromatin negative, the extra $C$ group member would be an autosome. The combination of Ctrisomy, D-monosomy, and absence of the $\mathrm{Y}$ would, even in mosaic form, almost certainly be lethal.

The karyotypes might also be interpreted as a G/D translocation involving a 21 or 22 but not the $\mathrm{Y}$; this assumes that the zygote was a normal $46 / \mathrm{XY}$ cell and that an abnormal first mitotic division produced a $\mathrm{D} / \mathrm{G}$ autosome translocation. There are three objections to this interpretation.

First, careful examination of all karyotyped cells and of many more under the microscope showed no short acrocentrics with the morphological features of the $\mathrm{Y}$ chromosome. Second, the cells without the translocation, the majority of the patient's cells, would be monosomic for a G-group chromosome. This has been reported in mosaic form in Lejeune's 'anti-mongol', (Lejeune, Berger, Rethore, Archambault, Jerome, Thieffry, Aicardi, Broyer, Lafourcade, Cruveiller, and Turpin, 1964) but that patient had many anomalies and died at 7 months. Third, if all cells had a Y chromosome, there would be no obvious reason for the anomalous sex phenotype.

Thus, the most plausible interpretation of the cytogenetic findings is mosaicism for a Y/D translocation. We assume that the mosaicism is the outcome of two errors. The first is an interchange which we postulate has occurred at the chromatid stage between one chromatid of the replicated Y chromosome and one of a D chromosome, presumably with loss of some of the short arm of each. Subsequently at cell division loss through anaphase lag of the other $\mathrm{Y}$ chromatid would have occurred with formation of an $\mathrm{XO}$ cell line. It is possible that the first error contributes to the occurrence of the second by interfering with the normal mechanism for segregation of the replicated chromosomes.

A second possible explanation is that the zygote had a karyotype with 45 chromosomes and a Y/D translocation, the result of a meiotic Y-translocation in spermatogenesis, and that in an early division there was breakage deletion and loss of the $Y$ fragment from one cell line. This seems inherently less likely.

The occurrence of testicular tissue in the seeming absence of a $\mathrm{Y}$ chromosome has been reported 
in about 25 cases (Strauch, Engel, Taft, Atkins, and Forbes, 1965), and has been attributed to undemonstrated mosaicism or to an undetected translocation of the $\mathrm{Y}$ to an autosome. On the basis of blood findings alone, the present patient would be classified as $45 / \mathrm{XO}$, but mosaicism was detected on gonadal culture. As others have pointed out, however, the absence of demonstrable mosaicism is not definitive, since the crucial cells may not be growing in tissue culture.

A Y/autosome translocation can be equally elusive, especially since it is not known how much of the $\mathrm{Y}$ is needed to evoke testicular development. Deletion of the short arm (Ferguson-Smith, 1965) seems to produce rudimentary testes plus Turner's stigmata. The patient described by Conen, Bailey, Allemang, Thompson, and Ezrin (I96I) had mixed gonadal dysgenesis with most of the long arm of the $\mathrm{Y}$ apparently missing. Court-Brown, Harnden, Jacobs, Maclean, and Mantle (1964) and Jacobs and Ross (1966) reported patients with a presumptive isochromosome for the long arm of the Y: both were phenotypic females of normal stature with streak gonads. Jacobs inferred that the determinants of the testis were on the short arm. Our case would put them on the long arm unless some material from the presumably absent short arm had undergone pericentric inversion. Muldal and Ockey (1962) reported several males with long arm deletion who had hypospadias but testes. These and several other cases suggest that the testis determinants may be contained in only a short segment of the Y. Translocation of such a small piece to an autosome larger and of less distinctive morphology than a D chromosome could easily be overlooked by current methods. In one previous case, a chromatin-positive male infant with hypospadias, translocation of fragments of a $\mathrm{Y}$ was postulated (Lamy, de Grouchy, Frezal, Josso, and Feintuch 1962). More recently, Ferguson-Smith (I966) suggested that interchange of material between homologous regions of the $\mathrm{X}$ and $\mathrm{Y}$ occurring in meiosis would account for testicular tissue in patients with no $\mathrm{Y}$ chromosome.

\section{Summary}

Endocrine and cytogenetic investigations of a 23-year-old chromatin negative woman with mixed gonadal dysgenesis are reported. The endocrine function of the single testis was shown to be that of an adult male. Cytogenetic analysis of six tissues showed a uniform modal number of 45 with karyotype mosaicism, some cells being XO and others interpreted as showing a Y/D translocation.

We gratefully acknowledge the technical assistance of Miss Annelise Baerlocher and Miss Kay Boling. Dr. Anne Forbes kindly performed the dermatoglyphic analysis, Dr. Priscilla Taft the sex chromatin study, and Dr. Leonard Atkins the cytogenetic study of the patient's father.

\section{REFERENCES}

Conen, P. E., Bailey, J. D., Allemang, W. H., Thompson, D. W. and Ezrin, C. (196I). A probable partial deletion of the Y chromosome in an intersex patient. Lancet, $2,294$.

Court-Brown, W. M., Harnden, D. G., Jacobs, P. A., Maclean, N., and Mantle, D. J. (I964). Abnormalities of the sex chromosome complement in man. Spec. Rep. Ser. med. Res. Coun. (Lond.), 305, 135 .

Epstein, E. (1962). An aqueous Zimmerman reagent for the determination of 17-ketosteroids. Clin. chim. Acta, 7, 735.

Ferguson-Smith, M. A. (1965). Karotype-phenotype correlations in gonadal dysgenesis and their bearing on the pathogenesis of malformations. F. med. Genet., $2,142$.

- (1966). X-Y chromosomal interchange in the aetiology of true hermaphroditism and of XX Klinefelter's syndrome. Lancet, 2, 475 .

, and Handmaker, S. D. (1963). The association of satellited chromosomes with specific chromosomal regions in cultured human somatic cells. Ann. hum. Genet., 27, 143.

Greenblatt, R. B. (1958). Clinical aspects of sexual abnormalities in man. Recent Progr. Hormone Res., 14, 335.

Jacobs, P. A., and Ross, A. (1966). Structural abnormalities of the $\mathrm{Y}$ chromosome in man. Nature (Lond.), $210,352$.

Kliman, B., and Briefer, C. (1964). Gas liquid chromatography of carbon-14 and tritium labeled steroids. Abstracts, Endocrine Society 46th Meeting.

Klinger, H. P., and Schwarzacher, H. G. (1962). XY/XXY and sex chromatin positive cell distribution in a $60 \mathrm{~mm}$ human fetus. Cytogenetics, I, 266.

Lamy, M., de Grouchy, J., Frezal, J., Josso, N., and Feintuch, G. (I962). Syndrome de Klinefelter et hypospadias. C.R. Acad. Sci. (Paris), 255, 581 .

Lejeune, J., Berger, R., Rethore, M., Archambault, L., Jerome, H., Thieffry, S., Aicardi, J., Broyer, M., Lafourcade, J., Cruveiller, J., and Turpin, R. (1964). Monosomie partielle pour un petit acrocentrique. ibid., 259, 4187.

Moorhead, P. S., Nowell, P. C., Mellman, W. J., Battips, D. M., and Hungerford, D. A. (1960). Chromosome preparations of leukocytes cultured from human peripheral blood. Exp. Cell Res., 20,613 .

Muldal, S., and Ockey, C. H. (1962). Deletion of Y chromosome in a family with muscular dystrophy and hypospadias. Brit. med. F. I, 291 .

Silber, R. H., and Porter, C. C. (1954). The determination of 17 , $2 \mathrm{I}$-dihydroxy-20-ketosteroids in urine and plasma. 7. biol. Chem., 210, 923.

Sohval, A. R. (1964). Hermaphroditism with "atypical" or "mixed" gonodal dysgenesis. Amer. F. Med., 36, 281

Strauch, G., Engel, E., Taft, P. D., Atkins, L., and Forbes, A. P. (1965). Syndrome de Klinefelter a caryotype $46 / \mathrm{XX}$ aux niveaux cutane, sanguin et testiculaire. Ann. endocr. (Paris), 26, 727. 